DOI: https://doi.org/10.47405/mjssh.v5i7.447

\begin{tabular}{|c|c|}
\hline 4 & Malaysian Journal of Social Sciences and Humanities (MJSSH) \\
\hline $\begin{array}{l}\text { Malaysian Journal of } \\
\text { Social sciences and }\end{array}$ & Volume 5, Issue 7, July 2020 \\
\hline (MJ-SSH) & e-ISSN : 2504-8562 \\
\hline & $\begin{array}{l}\text { Journal home page: } \\
\text { www.msocialsciences.com }\end{array}$ \\
\hline
\end{tabular}

\title{
Realiti Daya Hidup Bahasa Bisaya Muslim Sebagai Etnik Minoriti di Sabah
}

\author{
Md. Roslan Suhailin' ${ }^{1}$, Arba'ie Sujud' ${ }^{1}$, Rozita Che Rodi' ${ }^{1}$, Sharil Nizam Sha'ri' \\ 1Fakulti Bahasa Moden dan Komunikasi, Universiti Putra Malaysia (UPM) \\ Correspondence: Md. Roslan Suhailin (mdroslan30@yahoo.com)
}

\begin{abstract}
Abstrak
Kajian ini bertujuan untuk menentukan daya hidup bahasa etnik Bisaya Muslim di Beaufort, Sabah. Sebanyak 205 pelajar menengah atas dari tiga buah sekolah telah dipilih sebagai peserta melalui pensampelan rawak. Pengkaji menggunakan enam set soal selidik daripada model UNESCO. Hasil kajian menunjukkan bilangan penutur mutlak bahasa Bisaya dan transmisi bahasa antara generasi adalah terancam. Bahasa Bisaya dituturkan oleh kebanyakan generasi ibu bapa dan ke atas. Trend dalam domain penggunaan bahasa juga telah berkurangan. Walaupun bahasa Bisaya masih digunakan di rumah, bahasa Melayu yang dominan mula menular ke dalam domain keluarga. Respons terhadap domain dan media baharu masih bertahan manakala bahan untuk pendidikan dan literasi bahasa Bisaya ditafsirkan sebagai wujud dalam bentuk bahan bertulis yang hanya bermanfaat untuk sebahagian ahli masyarakat sahaja. Bahasa Bisaya mungkin ada kepentingan simbolik tetapi bukanlah sebahagian daripada kurikulum sekolah. Kesimpulannya, realiti daya hidup bahasa Bisaya Muslim menggambarkan prasyarat lazim ke arah bahasa terancam seperti tertera dalam model UNESCO meskipun penutur belum beralih ke bahasa lain. Pengkaji menyarankan agar kerangka etnolinguistik revitalisasi bahasa Bisaya di Beaufort, Sabah diimplementasikan sebagai projek perintis bagi program pemuliharaan bahasa.
\end{abstract}

Kata kunci: Bisaya Muslim, daya hidup bahasa, etnik minoriti, Borneo Utara, transmisi bahasa antara generasi

\section{The Reality of Bisaya Muslim Language Vitality as an Ethnic Minority in Sabah}

\begin{abstract}
This study aimed to determine the language vitality of the minority Bisaya Muslim in Beaufort, Sabah. A total of 205 upper secondary school students from three schools was chosen as participants by means of random sampling. The researchers used six sets of the questionnaire derived from the UNESCO model. Results have shown the absolute number of Bisaya speakers and intergenerational language transmission are in fact endangered. The language is used mostly by the parental generation and up. Trend in the domains of language use was also found to be dwindling. Although the Bisaya language is still used at home, the more dominant Malay language has begun to penetrate into family domains. Responses to the new domain and media remain steady whereas materials for the language education and literacy in the form of written materials are available, which are found to be beneficial for certain members of the community. The Bisaya language may have a symbolic significance, but it is definitely not part of the school curriculum. In conclusion, the reality of the Bisaya Muslim language vitality reflects a common prerequisite towards an endangered language as shown in UNESCO model even though the speakers have not shifted to use another language. It is recommended that the
\end{abstract}


ethnolinguistic framework for the Bisaya language revitalisation in Beaufort, Sabah be implemented as a pilot project for the language conservation programme.

Keywords: Bisaya Muslim, language vitality, ethnic minority, North Borneo, intergenerational language transmission

\section{Pengenalan}

Bahasa ialah mekanisme utama dalam menyalurkan pengetahuan leluhur, kehidupan, budaya dan identiti masyarakat pribumi. Sekurang-kurangnya 43 peratus daripada 6,000 bahasa dunia dianggarkan terancam. Kebanyakan bahasa yang terancam ini ialah bahasa pribumi. Era globalisasi memberi kesan kepada semua bahasa di dunia. Sebagai contoh, di benua Australia pada zaman pemukiman Eropah terdapat kira-kira 250 bahasa pribumi yang wujud. Akan tetapi statistik menunjukkan dalam tempoh 300 tahun ini sekurang-kurangnya 205 daripada 250 bahasa tersebut telah pupus atau dalam risiko terancam. Di Persekutuan Rusia, beberapa bahasa kini mempunyai penutur kurang daripada sepuluh orang (United Nations, 2012).

Banyak kebimbangan tentang kepupusan bahasa pribumi akibat pengenalan bahasa arus perdana sebagai bahasa kebangsaan dan bahasa dalam sistem pendidikan nasional. UNESCO menganggarkan kira-kira sembilan puluh peratus daripada semua bahasa di dunia boleh diganti dengan bahasa yang dominan menjelang akhir abad ke-21 (Brenzinger et al., 2003). Selain itu, terdapat masyarakat pribumi yang percaya bahasa mereka tiada nilai ekonomi. Oleh sebab itu, mereka meninggalkan bahasa dan budaya leluhur mereka dengan harapan dapat mengatasi diskriminasi, meningkatkan mobiliti sosial atau berasimilasi dengan bahasa yang berprestij. Bahasa pribumi biasanya dituturkan oleh minoriti individu di dalam sesebuah negeri yang dari segi sejarah tertakluk kepada dasar asimilasi. Penghijrahan penduduk pribumi ke bandar akibat tekanan ekonomi secara tidak langsung memisahkan mereka dari wilayah bahasa leluhur yang sekali gus memulakan proses asimilasi. Misalnya, masyarakat Bisaya di Kampung Bebuloh, Brunei telah berasimilasi dengan masyarakat Dusun. Di sekitar akhir tahun 80-an dan 90-an mereka mula berasimilasi dengan masyarakat Melayu Brunei yang lebih berprestij berbanding masyarakat Dusun. Tiga generasi masyarakat Bisaya di kampung itu kini mengamalkan budaya yang berbeza daripada generasi awal. Mereka yang berumur 50 tahun ke atas masih mengamalkan budaya leluhur dan kekal penutur asli bahasa Bisaya. Dalam situasi tertentu, pertuturan generasi yang berumur antara 30-50 tahun silih berganti dengan bahasa Dusun. Generasi yang berumur 30 tahun ke bawah kebanyakannya mengamalkan budaya dan bahasa Melayu Brunei. Sebaliknya, kadar perubahan daripada bahasa Bisaya kepada bahasa Melayu Brunei agak perlahan di Limbang, Sarawak, Malaysia berbanding bahasa Bisaya di Brunei. Generasi muda dan ibu bapa masih menggunakan bahasa Bisaya di rumah. Hal ini kerana ketegaran bahasa Bisaya di Limbang adalah disebabkan faktor kawasan geografi (Yabit, 2019).

Etnik Bisaya Muslim di Borneo Utara terdiri daripada pribumi Sabah, Sarawak dan Brunei. Penempatan utama etnik Bisaya Muslim di Sabah terletak di kawasan barat Beaufort di sepanjang Padas Damit, Gramma dan Sungai Padas. Perkampungan Bisaya di sepanjang Sungai Klias bercampur dengan perkampungan etnik Dusun (Dunn, 1984). Pengkaji terdahulu seperti Harrisson (1962) merujuk etnik Bisaya di Sabah sebagai pesawah Muslim yang mendiami kawasan di sepanjang hilir Sungai Padas dan Sungai Klias tetapi majoriti tinggal di Beaufort. Etnik Bisaya ialah penduduk pertama di Borneo Utara yang menerima Islam sebagai agama mereka pada abad ke-13. Pada masa kini sembilan puluh peratus etnik Bisaya di Sabah telah memeluk agama Islam manakala di Sarawak kebanyakannya beragama Kristian. Terdapat juga etnik Bisaya di Manunggang, Sabah yang pagan. Berdasarkan fakta sejarah, Awang Alak Betatar ialah pemimpin pertama etnik Bisaya. Setelah memeluk agama Islam beliau dikenali dengan nama Muhammad Shah (Liquisearch, 2019). Etnik Bisaya di Limbang, Sarawak ialah kerabat terdekat penduduk Bisaya di Sabah. Mereka ialah kelompok sosiopolitik yang berdamping dengan Kesultanan Brunei pada masa lampau (Okushima, 2003). Mereka dikhabarkan ada hubungan salasilah dengan Sultan Brunei yang pertama. Kebanyakan saki baki kelompok ini terdapat di sekitar Teluk Brunei (Lobel 2013). Sebahagian besar penempatan masyarakat Bisaya Muslim di 
Sabah bertumpu di barat Beaufort sepanjang Sungai Padas, di selatan Pekan Weston dan selatan Kuala Penyu seperti yang tertera dalam Rajah 1.

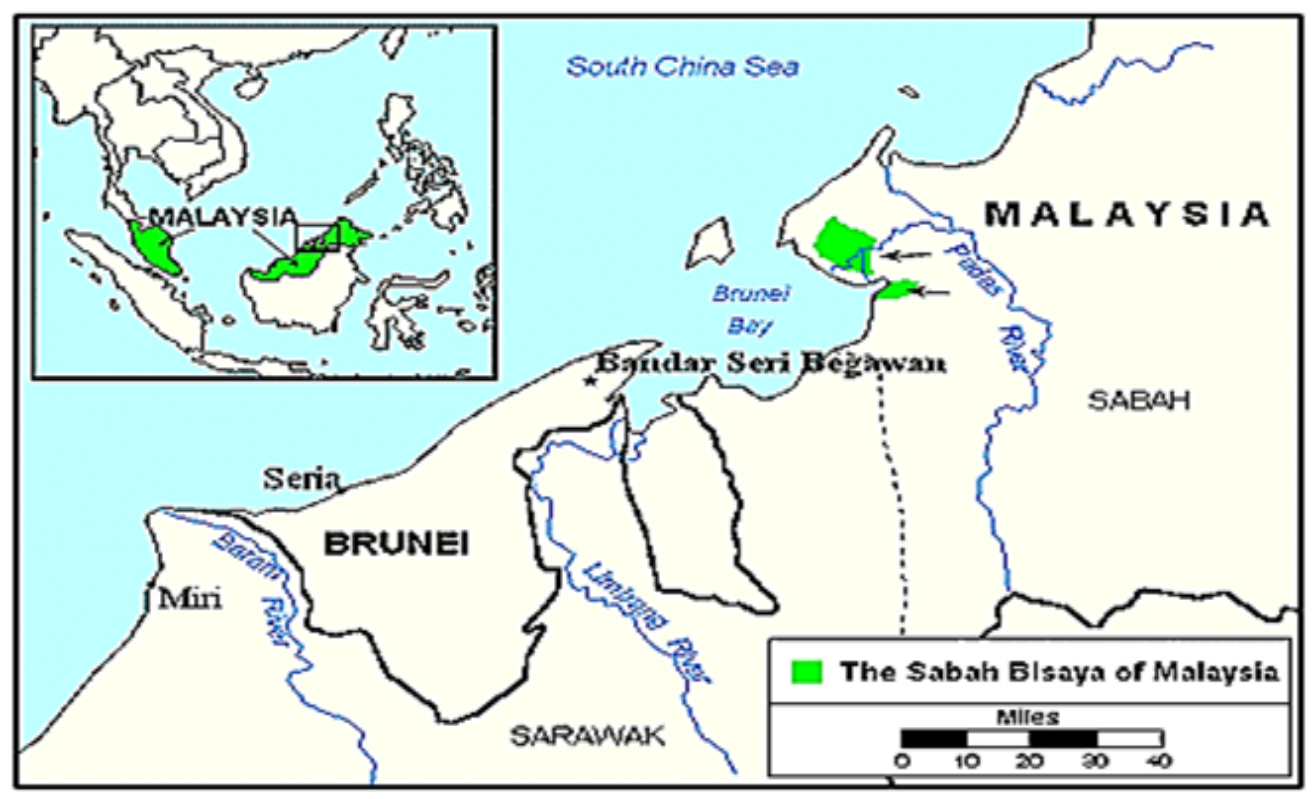

Rajah 1: Kawasan bahasa Bisaya di Beaufort, Sabah Sumber: Joshua Project (2019)

Sebelum tahun 1965 tiada sebarang penyelidikan tentang orang Islam di Sabah termasuk etnik Bisaya. Hanya selepas tempoh tersebut, barulah dilaksanakan beberapa penyelidikan linguistik oleh pengkaji dari barat (Aminah, 2012). Bahasa Bisaya di Sabah menurut sumber pengkaji terdahulu didapati berada pada tahap 'kecil', iaitu kurang daripada 10,000 penutur. Dalam awan bahasa (language cloud) indikator daya hidup bahasa Bisaya di Sabah ditandai warna merah yang bermaksud "Sudah tidak menjadi kelaziman kanak-kanak belajar dan menggunakan bahasa ini" (It is no longer the norm that children learn and use this language). Dengan kata lain, kanak-kanak tidak menggunakan bahasa Bisaya dalam domain rumah (Eberhard, Gary \& Charles 2019).

\section{Sorotan Literatur}

Terdapat beberapa kajian tentang daya hidup bahasa pribumi di Malaysia (Yabit, 2019; Noriah \& Nor Hasimah, 2012; Fatimah \& Najib, 2017; Chong, Hendrikus \& Collins, 2018; Coluzzi, Riget \& Xiaomei, 2017; dan Noor Aina et al., 2019). Sebahagian daripada hasil kajian mereka dipetik dan dibandingkan dengan dapatan daya hidup bahasa etnik Bisaya Muslim di daerah Beaufort, Sabah.

Bahasa Bisaya di Limbang, Sarawak masih digunakan sebagai bahasa ibunda disebabkan kawasan geografi. Sebaliknya, di kawasan bandar seperti Kota Kinabalu ramai etnik Bisaya yang menggunakan bahasa campuran Melayu dan bahasa ibunda malahan ada yang menggunakan bahasa Melayu sepenuhnya dalam domain rumah. Daerah Beaufort terletak di pedalaman Sabah. Oleh itu, ada kebarangkalian faktor kawasan geografi mempengaruhi pilihan penggunaan bahasa Bisaya dalam domain rumah (Yabit, 2019). Data daripada soal selidik tentang daya hidup bahasa lain, misalnya bahasa Sihan di Sarawak dianalisis menggunakan model daya hidup bahasa (UNESCO, 2003). Daya hidup bahasa Sihan berada pada Gred 3, iaitu domain yang semakin berkurangan. Hal ini bermakna bahasa Sihan masih digunakan di rumah tetapi bahasa dominan, iaitu bahasa Melayu telah mula menembusi domain rumah (Noriah \& Nor Hashimah, 2012).

Prestij bahasa yang lebih rendah didapati berasimilasi dengan bahasa yang berfungsi sebagai bahasa tempatan di Brunei (Fatimah \& Najib, 2015). Hal ini dapat dihubungkaitkan dengan pelajar etnik 
Bisaya kerana mereka mempunyai kecekapan bahasa Bisaya yang lemah berbanding generasi terdahulu. Faktor lain seperti penghijrahan dan agama juga mempengaruhi daya hidup bahasa Bisaya. Pelajar etnik Bisaya di Beaufort, Sabah beragama Islam sama seperti suku Penan Muslim di Kampung Jambatan Suai di kawasan pesisir pantai utara Sarawak. Semua penghuni di kampung tersebut ialah suku Penan Muslim. Bahasa yang dominan di kampung itu ialah bahasa Bintulu. Bahasa Penan hanya dikuasai oleh golongan tua. Hasil kajian ini memberi implikasi yang penting khususnya dalam isu memilih bahasa yang sinonim dengan agama Islam mengikut konteks Borneo Barat. Dalam hal ini, adalah satu kelaziman masyarakat bukan Melayu setelah beragama Islam akan memilih dialek Melayu setempat sebagai bahasa ibunda kerana dialek Melayu menampilkan identiti orang yang beragama Islam (Chong, Hendrikus \& Collins, 2018).

Satu lagi contoh kajian daya hidup bahasa peribumi ialah trend penggunaan bahasa Mah Meri dalam keluarga Orang Asli yang menunjukkan peralihan ke bahasa Melayu. Walaupun bahasa ibunda masih digunakan dan dihargai oleh masyarakat itu, generasi muda lebih cenderung menggunakan bahasa Melayu. Data ini meletakkan kedudukan bahasa Mah Meri sebagai bahasa yang terancam (Coluzzi, Riget \& Xiaomei, 2017). Terdapat satu kajian tentang transmisi bahasa antara generasi dalam kalangan etnik Dusun Islam di Sabah. Bahasa Bisaya amat rapat rumpunnya dengan bahasa Dusun. Hasil kajian menunjukkan bahasa ibunda telah hilang keistimewaannya sebagai bahasa pertuturan di rumah dalam kalangan generasi muda. Meskipun belum sampai ke tahap pupus, penggunaan seharian bahasa itu semakin menyusut dan komuniti penutur beransur-ansur beralih menggunakan bahasa Melayu. Faktor luaran seperti keperluan sosial telah mencetuskan perubahan yang lebih luas daripada sekadar pengambilan leksikal bahasa Melayu ke dalam kosa kata bahasa ibunda (Noor Aina et al., 2019).

\section{Metod Kajian}

Konsep daya hidup bahasa berkait rapat dengan kecenderungan kumpulan berperilaku sebagai entiti kolektif yang distingtif dan aktif dalam situasi antara kumpulan (Giles, Bourhis \& Taylor, 1977). Skop kajian ini merangkumi daya hidup bahasa etnik Bisaya Muslim di daerah Beaufort, Sabah. Kaedah tinjauan dengan enam set soal selidik dilaksanakan di SMK Beaufort II, SMK Kota Klias dan SMK Gadong. Sebanyak 205 pelajar menengah atas yang terdiri daripada etnik Bisaya Muslim dipilih sebagai peserta kajian. Jadual 1 memaparkan nama sekolah dan jumlah peserta kajian yang terlibat.

Jadual 1: Profil Peserta Kajian

\begin{tabular}{ccccc}
\hline Nama Sekolah & $\begin{array}{c}\text { Jumlah } \\
\text { Peserta } \\
\text { Lelaki }\end{array}$ & $\begin{array}{c}\text { Jumlah Peserta } \\
\text { Perempuan }\end{array}$ & $\begin{array}{c}\text { Kadar } \\
\text { Peratus } \\
\mathbf{( \% )}\end{array}$ & $\begin{array}{c}\text { Jumlah Peserta } \\
\text { Kajian }\end{array}$ \\
\hline SMK Kota Klias & 32 & 35 & 32.68 & 67 \\
SMK Beaufort II & 26 & 28 & 26.34 & 54 \\
SMK Gadong & 32 & 52 & 40.98 & 84 \\
& 90 & 115 & 100 & 205 \\
\hline
\end{tabular}

Dalam penyelidikan daya hidup bahasa terdapat beberapa model seperti Graded Intergenerational Disruption Scales (GIDS) yang dipelopori oleh Fishman (1991), Expanded GIDS (Lewis \& Simons, 2009) dan UNESCO Ad Hoc Expert Group on Endangered Languages (Brenzinger et al., 2003). Setiap model menggunakan indikator tahap ancaman daya hidup bahasa. Fokus penyelidikan terawal ialah minoriti imigran, bahasa pribumi dan bahasa yang terancam. Model terawal penilaian daya hidup bahasa telah dihasilkan oleh panel pakar bahasa UNESCO (Brenzinger et al., 2003). Model ini menyediakan 6 faktor utama daya hidup bahasa merangkumi (a) Transmisi bahasa antara generasi, (b) Bilangan penutur mutlak, (c) Perkadaran penutur dalam jumlah penduduk, (d) Trend dalam domain bahasa sedia ada, (e) Respons terhadap domain dan media baharu, serta (f) Bahan untuk pendidikan bahasa dan literasi. Faktor (a) ialah faktor terpenting yang diadaptasi oleh panel pakar bahasa UNESCO daripada Fishman (1991). Semua faktor perlu ditinjau bagi memperoleh daya hidup sesuatu bahasa. Setiap faktor tersebut mempunyai skala berperingkat dari gred 0 hingga 5. 
Ujian kebolehpercayaan telah dilaksanakan bagi 24 item soal selidik yang telah dijawab oleh 146 peserta kajian ini (68 lelaki dan 78 perempuan). Ujian Alpha Cronbach berdasarkan item terpiawai (standardized items) dikira dengan menggunakan perisian IBM SPSS Statistiks 23. Nilai statistik 0.954 yang diperoleh menunjukkan konsistensi dalaman yang sangat baik. Kajian ini menghasilkan satu dimensi data dalam kalangan pelajar etnik Bisaya Muslim dari tiga buah sekolah menengah di Beaufort, Sabah. Selain menggunakan model daya hidup bahasa UNESCO, pengkaji memanfaatkan soal selidik tentang pilihan penggunaan bahasa dalam domain khusus dari sumber Drummond (2010). Soal selidik tersebut mengandungi 3 soalan dengan 5 jawapan pilihan. Ujian Alpha Cronbach yang dilaksanakan ke atas 10 item daripada 146 peserta kajian menghasilkan nilai 0.966, iaitu konsistensi dalaman yang sangat baik.

\section{Hasil Kajian}

\section{Transmisi Bahasa Antara Generasi}

Data dalam Jadual 2 menunjukkan tahap ancaman daya hidup dari segi transmisi bahasa Bisaya antara generasi tua dengan generasi muda.

Jadual 2: Transmisi Bahasa Antara Generasi

\begin{tabular}{|c|c|c|c|c|c|c|}
\hline \multicolumn{7}{|c|}{ Faktor 1: Transmisi Bahasa Bisaya Antara Generasi } \\
\hline $\begin{array}{l}\text { Tahap } \\
\text { Ancaman }\end{array}$ & Gred & Populasi Penutur & $\mathbf{L}$ & $\%$ & $\mathbf{P}$ & $\%$ \\
\hline Selamat & 5 & $\begin{array}{l}\text { Bahasa Bisaya digunakan dalam } \\
\text { semua peringkat usia, dari kanak- } \\
\text { kanak dan ke atas. }\end{array}$ & & & & \\
\hline Tidak selamat & 4 & $\begin{array}{l}\text { Bahasa Bisaya digunakan oleh } \\
\text { sebilangan kanak-kanak dalam semua } \\
\text { domain; digunakan oleh semua } \\
\text { kanak-kanak dalam domain terhad. }\end{array}$ & 22 & $\begin{array}{c}24.4 \\
2\end{array}$ & 20 & 17.4 \\
\hline Terancam & 3 & $\begin{array}{l}\text { Bahasa Bisaya digunakan oleh } \\
\text { kebanyakan generasi ibu bapa dan ke } \\
\text { atas. }\end{array}$ & 46 & $\begin{array}{c}51.0 \\
6\end{array}$ & 70 & 60.9 \\
\hline Sangat terancam & 2 & $\begin{array}{l}\text { Bahasa Bisaya digunakan oleh } \\
\text { kebanyakan generasi datuk nenek } \\
\text { dan ke atas. }\end{array}$ & 22 & $\begin{array}{c}24.4 \\
2\end{array}$ & 21 & 18.27 \\
\hline Kritikal & 1 & $\begin{array}{l}\text { Bahasa Bisaya digunakan oleh } \\
\text { segelintir orang, kebanyakan generasi } \\
\text { moyang. }\end{array}$ & & & 4 & 3.48 \\
\hline Pupus & 0 & Tiada penutur bahasa Bisaya. & 90 & 100 & 115 & 100 \\
\hline
\end{tabular}

Kumpulan pelajar lelaki memilih gred 3, 'terancam' dengan 46 respons (51.06\%). Pada tahap ancaman ini bahasa Bisaya digunakan oleh kebanyakan generasi ibu bapa dan ke atas. Ibu bapa masih boleh bercakap bahasa Bisaya kepada anak-anak mereka tetapi anak-anak lebih cenderung menggunakan bahasa Melayu. Tahap ancaman daya hidup bahasa Bisaya pilihan kumpulan pelajar perempuan ialah gred 3, 'terancam' dengan 70 respons bersamaan $60.9 \%$.

\section{Bilangan Penutur Mutlak}

Jadual 3 memaparkan bilangan penutur mutlak bahasa etnik Bisaya Muslim di Sabah. Status bahasa Bisaya ialah $6 \mathrm{~b}$ (Terancam). Populasi penutur bahasa Bisaya adalah kecil, iaitu kurang daripada 10,000 orang. Tiada penutur ekabahasa dalam kalangan etnik Bisaya Muslim kerana mereka menggunakan campuran bahasa ibunda dan dialek Melayu Sabah dalam domain kekeluargaan, pergaulan, keagamaan, 
DOI: https://doi.org/10.47405/mjssh.v5i7.447

pekerjaan dan pendidikan. Ramai juga yang pandai bertutur dalam bahasa Melayu Brunei. Walau bagaimanapun, mereka masih bersikap positif terhadap bahasa Bisaya. Pembangunan bahasa Bisaya memperlihatkan kadar literasi penutur sebanyak 40\%. Sebaliknya, kadar literasi dalam bahasa Melayu standard sebanyak 70\% jelas lebih tinggi daripada bahasa Bisaya (Eberhard, Gary \& Charles, 2019).

Jadual 3: Bilangan Penutur Mutlak

\begin{tabular}{|c|c|}
\hline $\begin{array}{l}\text { Bahasa } \\
\text { Bisaya }\end{array}$ & $\begin{array}{l}\text { Faktor 2: Bilangan Penutur Mutlak Bahasa Bisaya di } \\
\text { Sabah }\end{array}$ \\
\hline ISO 639-3 & Bys \\
\hline Nama lain & Basaya, Besaya, Bisaia, Bisayah, Jilama Bawang, Jilama Sungai \\
\hline Populasi & $\begin{array}{l}\text { Kecil - Bahasa ini mempunyai penutur kurang daripada } 10,000 \text { orang. } \\
\text { Tiada penutur ekabahasa. }\end{array}$ \\
\hline Lokasi & $\begin{array}{l}\text { Sabah: daerah Beaufort dan Kuala Penyu, kawasan pantai Teluk Brunei } \\
\text { Utara, terutamanya sepanjang Sungai Klias dan Padas, di selatan } \\
\text { Weston; Sarawak: Batu Danau, Limbang. }\end{array}$ \\
\hline Status Bahasa & $6 \mathrm{~b}($ Terancam $)$ \\
\hline Klasifikasi & Austronesia, Malayo-Polinesia, Borneo Utara. \\
\hline Dialek & $\begin{array}{l}\text { Bisaya Klias, Bisaya Kuala Penyu, Bisaya Padas, Bisaya Beaufort, } \\
\text { Bisaya Limbang. } 70 \% \text { kesalingfahaman dengan dialek Bisaya Sabah dan } \\
\text { Tatana. Persamaan leksikal: 53\% sama dengan Bisaya Brunei (dialek } \\
\text { Sarawak), 52\% dengan Bisaya Brunei (dialek Brunei). }\end{array}$ \\
\hline $\begin{array}{l}\text { Penggunaan } \\
\text { Bahasa }\end{array}$ & $\begin{array}{l}\text { Bercampur: Di rumah, Rakan-rakan, Agama, Kerja, Pendidikan. Dalam } \\
\text { sebilangan penutur muda, semua orang dewasa. Bersikap positif. Semua } \\
\text { menggunakan bahasa Melayu Sabah juga. Ramai juga yang guna bahasa } \\
\text { Melayu Brunei. }\end{array}$ \\
\hline Pembangunan & Kadar literasi dalam B1: 40\%. Kadar literasi dalam B2: 70\% Bahasa \\
\hline Bahasa & Melayu standard. \\
\hline Tulisan & Skrip Latin \\
\hline Lain-lain & Muslim \\
\hline
\end{tabular}

\section{Perkadaran Penutur dalam Jumlah Penduduk}

Perkadaran penutur bahasa Bisaya dalam jumlah penduduk berdasarkan pilihan kumpulan pelajar lelaki dalam Jadual 4 berada pada gred 3, 'terancam' dengan respons sebanyak 44 (48.84\%). Data ini ditafsirkan sebagai majoriti etnik Bisaya Muslim masih bertutur bahasa Bisaya tetapi kanak-kanak tidak menggunakan bahasa itu di rumah. Penutur termuda ialah generasi ibu bapa. Perkadaran penutur bahasa Bisaya dalam jumlah penduduk mengikut pilihan kumpulan pelajar perempuan berada pada gred 4, iaitu 'tidak selamat'. Sebanyak 49 respons atau $42.63 \%$ diperoleh daripada kumpulan ini. Gred 4 bermaksud kebanyakan tetapi bukan semua kanak-kanak atau keluarga komuniti Bisaya menuturkan bahasa itu sebagai bahasa pertama.

Jadual 4: Perkadaran Penutur dalam Jumlah Penduduk

\begin{tabular}{lcccccc}
\hline \multicolumn{6}{c}{ Faktor 3: Perkadaran Penutur Bahasa Bisaya dalam Jumlah Penduduk } \\
\hline $\begin{array}{l}\text { Tahap } \\
\text { Ancaman }\end{array}$ & Gred & \multicolumn{1}{c}{ Populasi Penutur } & L & $\%$ & P & \% \\
\hline Selamat & 5 & $\begin{array}{l}\text { Semua kaum Bisaya } \\
\text { bertutur bahasa Bisaya. }\end{array}$ & & 1 & 0.87 \\
Tidak selamat & 4 & $\begin{array}{l}\text { Hampir semua kaum Bisaya } \\
\text { bertutur bahasa Bisaya. } \\
\text { Majoriti kaum Bisaya } \\
\text { bertutur bahasa Bisaya. }\end{array}$ & 27 & 29.97 & 49 & 42.63 \\
Terancam & 3 & 48.84 & 47 & 40.89 \\
\hline
\end{tabular}


DOI: https://doi.org/10.47405/mjssh.v5i7.447

\begin{tabular}{|c|c|c|c|c|c|c|}
\hline Sangat terancam & 2 & $\begin{array}{l}\text { Minoriti kaum Bisaya } \\
\text { bertutur bahasa Bisaya. }\end{array}$ & 16 & 17.76 & 15 & 13.05 \\
\hline Kritikal & 1 & $\begin{array}{l}\text { Sangat sedikit kaum Bisaya } \\
\text { bertutur bahasa Bisaya. }\end{array}$ & 3 & 3.33 & 3 & 2.61 \\
\hline \multirow[t]{2}{*}{ Pupus } & 0 & $\begin{array}{l}\text { Tiada penutur bahasa } \\
\text { Bisaya. }\end{array}$ & & & & \\
\hline & & & 90 & 100 & 115 & 100 \\
\hline
\end{tabular}

Penggunaan bahasa Bisaya mungkin terhad dalam domain sosial seperti di rumah sewaktu kanakkanak berinteraksi dengan orang tua dan datuk nenek. Di mana, dengan siapa dan apa topik perbualan menentukan sama ada bahasa diturunkan kepada generasi seterusnya.

\section{Trend dalam Domain Penggunaan Bahasa Sedia Ada}

Berdasarkan Jadual 5, didapati kumpulan pelajar lelaki memilih gred 3, 'domain berkurangan' dengan respons $41(45.51 \%)$ manakala respons kumpulan pelajar perempuan pada gred yang sama adalah sebanyak $60(52.2 \%)$. Hal ini bermaksud bahasa Bisaya digunakan dalam domain rumah dan untuk banyak fungsi, tetapi bahasa Melayu yang dominan mula menular ke dalam domain keluarga. Kadar peratus respons daripada pelajar perempuan lebih tinggi daripada pelajar lelaki. Dapatlah dikatakan bahawa penggunaan bahasa Bisaya dalam domain sedia ada telah terjejas. Di rumah, ibu bapa mula menggunakan bahasa Melayu yang lebih dominan dalam komunikasi seharian dengan anak-anak yang dwibahasa reseptif. Meskipun ada komuniti bahasa di Sabah telah berjaya meluaskan bahasa ibunda dalam domain baharu, kebanyakannya tidak mendapat peluang sedemikian. Media baharu seperti penyiaran dan internet di Sabah lazimnya berfungsi bagi mengembangkan skop dan kuasa bahasa Melayu. Sungguhpun domain bahasa Bisaya yang sedia ada kekal berfungsi, penggunaan bahasa Melayu dan bahasa Inggeris dalam domain baharu seperti televisyen adalah lebih berpengaruh. Bahasa Bisaya perlu memenuhi cabaran moden dalam dunia penyiaran dan dunia siber agar bahasa itu tidak jumud.

Jadual 5: Trend dalam Domain Penggunaan Bahasa Sedia Ada

\begin{tabular}{|c|c|c|c|c|c|c|}
\hline \multicolumn{7}{|c|}{ Faktor 4: Trend dalam Domain Penggunaan Bahasa Sedia Ada } \\
\hline $\begin{array}{l}\text { Tahap } \\
\text { Ancaman }\end{array}$ & Gred & $\begin{array}{c}\text { Domain dan Fungsi Bahasa } \\
\text { Bisaya }\end{array}$ & $\mathbf{L}$ & $\%$ & $\mathbf{P}$ & $\%$ \\
\hline $\begin{array}{l}\text { Penggunaan } \\
\text { Sejagat }\end{array}$ & 5 & $\begin{array}{l}\text { Bahasa Bisaya digunakan } \\
\text { dalam semua domain dan } \\
\text { untuk semua fungsi. }\end{array}$ & & & & \\
\hline $\begin{array}{l}\text { Kesetaraan } \\
\text { multibahasa }\end{array}$ & 4 & $\begin{array}{l}\text { Dua atau lebih bahasa mungkin } \\
\text { digunakan dalam kebanyakan } \\
\text { domain sosial dan untuk } \\
\text { kebanyakan fungsi. }\end{array}$ & 10 & 11.1 & 15 & 13.05 \\
\hline $\begin{array}{l}\text { Domain } \\
\text { berkurangan }\end{array}$ & 3 & $\begin{array}{l}\text { Bahasa Bisaya digunakan } \\
\text { dalam domain rumah dan } \\
\text { untuk banyak fungsi, tetapi } \\
\text { bahasa Melayu yang dominan } \\
\text { mula menular ke dalam domain } \\
\text { keluarga. }\end{array}$ & 41 & 45.51 & 60 & 52.2 \\
\hline $\begin{array}{l}\text { Domain terhad } \\
\text { atau formal }\end{array}$ & 2 & $\begin{array}{l}\text { Bahasa Bisaya digunakan } \\
\text { dalam domain sosial yang } \\
\text { terhad dan untuk beberapa } \\
\text { fungsi formal. }\end{array}$ & 25 & 27.75 & 28 & 24.36 \\
\hline $\begin{array}{l}\text { Domain sangat } \\
\text { terhad }\end{array}$ & 1 & $\begin{array}{l}\text { Bahasa Bisaya hanya } \\
\text { digunakan dalam sebilangan } \\
\text { domain yang terbatas dan } \\
\text { untuk fungsi yang sangat } \\
\text { sedikit. }\end{array}$ & 12 & 13.32 & 12 & 10.44 \\
\hline
\end{tabular}


DOI: https://doi.org/10.47405/mjssh.v5i7.447

\begin{tabular}{lllllll}
\hline Pupus & 0 & $\begin{array}{l}\text { Bahasa Bisaya tidak digunakan } \\
\text { dalam sebarang domain untuk }\end{array}$ & 2 & 2.22 & & \\
& sebarang fungsi. & 90 & 100 & 115 & 100 \\
\hline
\end{tabular}

\section{Respons terhadap Domain dan Media Baharu}

Data dalam Jadual 6 menunjukkan kedua-dua kumpulan pelajar (lelaki dan perempuan) memilih tahap ancaman gred 2, 'bertahan' bagi respons terhadap domain dan media baharu.

Jadual 6: Respons terhadap Domain dan Media Baharu

\begin{tabular}{|c|c|c|c|c|c|c|}
\hline \multicolumn{7}{|c|}{ Faktor 5: Respons terhadap Domain dan Media Baharu } \\
\hline $\begin{array}{l}\text { Tahap } \\
\text { Ancaman }\end{array}$ & Gred & $\begin{array}{c}\text { Domain dan Fungsi Bahasa } \\
\text { Bisaya }\end{array}$ & $\mathbf{L}$ & $\%$ & $\mathbf{P}$ & $\%$ \\
\hline Dinamik & 5 & $\begin{array}{l}\text { Bahasa Bisaya digunakan dalam } \\
\text { semua domain baharu. }\end{array}$ & & & & \\
\hline Teguh / aktif & 4 & $\begin{array}{l}\text { Bahasa Bisaya digunakan dalam } \\
\text { kebanyakan domain baharu. }\end{array}$ & 4 & 4.44 & 7 & 6.09 \\
\hline Terbuka & 3 & $\begin{array}{l}\text { Bahasa Bisaya digunakan dalam } \\
\text { pelbagai domain baharu. }\end{array}$ & 26 & 28.86 & 33 & 28.71 \\
\hline Bertahan & 2 & $\begin{array}{l}\text { Bahasa Bisaya digunakan dalam } \\
\text { beberapa domain baharu. }\end{array}$ & 30 & 33.3 & 46 & 40.02 \\
\hline Minima & 1 & $\begin{array}{l}\text { Bahasa Bisaya digunakan hanya } \\
\text { dalam sedikit domain baharu. }\end{array}$ & 28 & 31.08 & 25 & 21.75 \\
\hline Tidak aktif & 0 & $\begin{array}{l}\text { Bahasa Bisaya tidak digunakan } \\
\text { dalam sebarang domain baharu. }\end{array}$ & $\begin{array}{c}2 \\
90\end{array}$ & $\begin{array}{c}2.22 \\
100\end{array}$ & $\begin{array}{c}4 \\
115\end{array}$ & $\begin{array}{l}3.48 \\
100\end{array}$ \\
\hline
\end{tabular}

\section{Bahan untuk Pendidikan Bahasa dan Literasi}

Data dalam Jadual 7 tentang bahan untuk pendidikan dan literasi bahasa Bisaya bagi kedua-dua kumpulan pelajar (lelaki dan perempuan) berada pada gred 2. Gred 2 ditafsirkan sebagai bahan bertulis ada dalam bahasa Bisaya tetapi hanya berguna untuk beberapa ahli masyarakat; bagi yang lain, bahasa itu mungkin ada kepentingan simbolik. Pendidikan literasi dalam bahasa Bisaya bukan sebahagian daripada kurikulum sekolah. Pendidikan dalam bahasa adalah penting untuk daya hidup bahasa Bisaya. Komuniti penutur bahasa Bisaya mengekalkan tradisi lisan tetapi literasi bukanlah sumber yang dapat dibanggakan.

Jadual 7: Bahan untuk Pendidikan Bahasa dan Literasi

\begin{tabular}{clcccc}
\hline \multicolumn{7}{c}{ Faktor 6: Bahan untuk Pendidikan Bahasa dan Literasi } \\
\hline Gred & $\begin{array}{c}\text { Adanya Bahan-bahan ditulis dalam Bahasa } \\
\text { Bisaya }\end{array}$ & L & \% & P & \% \\
\hline 5 & $\begin{array}{l}\text { Terdapat satu ejaan ditetapkan dan tradisi literasi } \\
\text { dengan tatabahasa, kamus, teks, sastera dan media } \\
\text { setiap hari. Bahasa Bisaya digunakan untuk } \\
\text { menulis dalam pentadbiran dan pendidikan. }\end{array}$ & 7 & 7.77 & & \\
$\begin{array}{l}\text { Bahan bertulis bahasa Bisaya ada, dan di sekolah } \\
\text { kanak-kanak ada kemajuan dalam literasi bahasa } \\
\text { itu. Bahasa itu tidak digunakan dalam pentadbiran. } \\
\text { Bahan bertulis dalam bahasa Bisaya ada dan } \\
\text { kanak-kanak mungkin terdedah kepada bentuk } \\
\text { bertulis di sekolah. Literasi bahasa itu tidak } \\
\text { dipromosikan melalui media cetak. }\end{array}$ & 14 & 15.54 & 10 & 8.7 \\
\hline
\end{tabular}


2 Bahan bertulis ada dalam bahasa Bisaya tetapi hanya berguna untuk beberapa ahli masyarakat; bagi yang lain, bahasa itu mungkin ada kepentingan simbolik. Pendidikan literasi dalam bahasa itu bukan sebahagian daripada kurikulum sekolah.

1 Ejaan yang praktikal dalam bahasa Bisaya diketahui masyarakat dan beberapa bahan sedang ditulis.

$0 \quad$ Tiada ejaan bahasa Bisaya disediakan kepada masyarakat. $\begin{array}{llll}31 & 34.41 \quad 46 \quad 40.02\end{array}$

$\begin{array}{llll}12 & 13.32 & 22 & 19.14\end{array}$

$\begin{array}{llll}3 & 3.33 & 1 & 0.87\end{array}$

$\begin{array}{llll}90 & 100 & 115 & 100\end{array}$

\section{Persoalan Kajian}

Persoalan kajian yang ingin dijawab oleh pengkaji ialah "Apakah maklumat daripada kaji selidik daya hidup bahasa etnik Bisaya Muslim yang dapat dimanfaatkan untuk revitalisasi bahasa Bisaya?" Maklumat daripada hasil kaji selidik yang berfaedah untuk revitalisasi bahasa Bisaya dipaparkan dalam Jadual 8 yang berikut.

Jadual 8: Penilaian Status dan Daya Hidup Bahasa Bisaya

\begin{tabular}{|c|c|c|c|}
\hline & Faktor & $\begin{array}{l}\text { Nama Bahasa: Bisa: } \\
\text { Kod ISO 639-3: bys }\end{array}$ & di daerah Beaufort, Sabah \\
\hline Bil. & & Penarafan & Tafsiran \\
\hline 1 & Bilangan penutur mutlak & $\begin{array}{l}\text { Kecil - Bahasa ini } \\
\text { mempunyai penutur } \\
\text { kurang daripada } \\
10,000 \text { orang } \\
\text { (Eberhard et al., } \\
\text { 2019). }\end{array}$ & $\begin{array}{l}\text { Tiada penutur ekabahasa. Lokasi: } \\
\text { Daerah Beaufort dan Kuala Penyu, } \\
\text { kawasan pantai Teluk Brunei Utara, } \\
\text { terutamanya sepanjang Sungai Klias } \\
\text { dan Padas, di selatan Weston. }\end{array}$ \\
\hline 2 & $\begin{array}{l}\text { Perkadaran penutur } \\
\text { bahasa Bisaya dalam } \\
\text { jumlah penduduk }\end{array}$ & Gred 3: Terancam & $\begin{array}{l}\text { Majoriti kaum Bisaya bertutur bahasa } \\
\text { Bisaya. }\end{array}$ \\
\hline 3 & $\begin{array}{l}\text { Transmisi bahasa Bisaya } \\
\text { antara generasi tua } \\
\text { dengan generasi muda }\end{array}$ & Gred 3: Terancam & $\begin{array}{l}\text { Bahasa Bisaya digunakan oleh } \\
\text { kebanyakan generasi ibu bapa dan ke } \\
\text { atas. }\end{array}$ \\
\hline 4 & $\begin{array}{l}\text { Trend dalam domain } \\
\text { penggunaan bahasa sedia } \\
\text { ada }\end{array}$ & $\begin{array}{l}\text { Gred 3: Domain } \\
\text { berkurangan }\end{array}$ & $\begin{array}{l}\text { Bahasa Bisaya digunakan dalam } \\
\text { domain rumah dan untuk banyak } \\
\text { fungsi, tetapi bahasa Melayu yang } \\
\text { dominan mula menular ke dalam } \\
\text { domain rumah. }\end{array}$ \\
\hline 5 & $\begin{array}{l}\text { Respons terhadap } \\
\text { domain dan media } \\
\text { baharu }\end{array}$ & Gred 2: Bertahan & $\begin{array}{l}\text { Bahasa Bisaya digunakan dalam } \\
\text { beberapa domain baharu. }\end{array}$ \\
\hline 6 & $\begin{array}{l}\text { Bahan untuk pendidikan } \\
\text { dan literasi bahasa }\end{array}$ & Gred 2: Bertahan & $\begin{array}{l}\text { Bahan bertulis ada dalam bahasa } \\
\text { Bisaya tetapi hanya berguna untuk } \\
\text { beberapa ahli masyarakat; bagi yang } \\
\text { lain, bahasa itu mungkin ada } \\
\text { kepentingan simbolik. Pendidikan } \\
\text { literasi dalam bahasa itu bukan } \\
\text { sebahagian daripada kurikulum } \\
\text { sekolah. }\end{array}$ \\
\hline
\end{tabular}


Terdapat beberapa tafsiran tentang penilaian status dan daya hidup bahasa etnik Bisaya Muslim di daerah Beaufort, Sabah. Bilangan penutur mutlak bahasa Bisaya di Sabah adalah kecil, iaitu kurang daripada 10,000 orang. Komuniti etnik Bisaya Muslim ialah penutur dwibahasa. Mereka menggunakan bahasa Bisaya dan dialek Melayu Sabah dalam komunikasi seharian. Terdapat dalam kalangan mereka yang fasih bertutur bahasa Melayu Brunei. Jumlah penutur yang kecil berisiko untuk berasimilasi ke dalam kumpulan penutur yang lebih besar. Hal ini menyebabkan transmisi bahasa Bisaya antara generasi tua dengan generasi muda dalam keadaan terancam. Bahasa Bisaya hanya digunakan oleh kebanyakan generasi ibu bapa dan ke atas.

Ringkasnya, bahasa Bisaya tidak dipelajari sebagai bahasa pertama oleh anak-anak di rumah. Penutur termuda ialah ibu bapa. Pada tahap ini, ibu bapa masih menggunakan bahasa Bisaya semasa berinteraksi dengan anak-anak, tetapi anak-anak tidak semestinya menjawab dalam bahasa Bisaya. Respons terhadap domain dan media baharu jatuh dalam gred 2: bertahan. Literasi bahasa ialah sumber kebanggaan sesebuah masyarakat. Literasi dapat mempengaruhi pembangunan sosial dan ekonomi. Pada masa ini pendidikan literasi dalam bahasa Bisaya bukan sebahagian daripada kurikulum sekolah. Oleh sebab itu, kadar literasi bahasa Melayu dalam kalangan etnik Bisaya Muslim lebih tinggi jika dibandingkan dengan bahasa Bisaya.

\section{Pilihan Bahasa dalam Domain Khusus oleh Pelajar Etnik Bisaya Muslim}

Dalam Jadual 9 yang berikut ialah data tentang pilihan bahasa dalam domain khusus oleh pelajar etnik Bisaya Muslim yang dikaji. Pilihan utama menggambarkan jumlah peratus bahasa yang digunakan oleh kumpulan pelajar lelaki dan perempuan pada hari biasa di sekolah adalah sebanyak $25 \%$ bahasa ibunda, $75 \%$ bahasa Melayu. Pada hari biasa di rumah, pilihan bahasa mereka adalah sebanyak $25 \%$ bahasa ibunda, $75 \%$ bahasa Melayu. Sewaktu bersama rakan, mereka turut memilih $25 \%$ bahasa ibunda, $75 \%$ bahasa Melayu.

Jadual 9: Pilihan bahasa dalam domain khusus oleh pelajar etnik Bisaya Muslim

\begin{tabular}{|c|c|c|c|c|c|}
\hline Bil. & Item & $\mathbf{L}$ & $\%$ & $\mathbf{P}$ & $\%$ \\
\hline 1 & $\begin{array}{l}\text { Yang manakah pilihan terbaik menggambarkan jumlah peratus } \\
\text { bahasa ibunda dan BM yang anda gunakan pada hari biasa di } \\
\text { sekolah? }\end{array}$ & & & & \\
\hline A & $100 \%$ Bahasa ibunda, $0 \% \mathrm{BM}$ & & & & \\
\hline B & $75 \%$ Bahasa ibunda, $25 \%$ BM & & & & \\
\hline $\mathrm{C}$ & $50 \%$ Bahasa ibunda, $50 \%$ BM & 21 & 23.31 & 16 & 13.92 \\
\hline $\mathrm{D}$ & 25\% Bahasa ibunda, $75 \%$ BM & 47 & 52.17 & 67 & 58.29 \\
\hline $\mathrm{E}$ & $0 \%$ Bahasa ibunda, $100 \%$ BM & 22 & 24.42 & 32 & 27.84 \\
\hline 2 & $\begin{array}{l}\text { Yang manakah pilihan terbaik menggambarkan jumlah peratus } \\
\text { bahasa ibunda dan BM yang anda gunakan pada hari biasa di } \\
\text { rumah? }\end{array}$ & 90 & 100 & 115 & 100 \\
\hline A & $100 \%$ Bahasa ibunda, $0 \% \mathrm{BM}$ & & & & \\
\hline B & $75 \%$ Bahasa ibunda, $25 \%$ BM & & & 2 & 1.74 \\
\hline $\mathrm{C}$ & $50 \%$ Bahasa ibunda, $50 \%$ BM & 17 & 18.87 & 30 & 26.1 \\
\hline $\mathrm{D}$ & 25\% Bahasa ibunda, $75 \%$ BM & 37 & 41.07 & 51 & 44.37 \\
\hline $\mathrm{E}$ & $0 \%$ Bahasa ibunda, $100 \%$ BM & 36 & 39.96 & 32 & 27.84 \\
\hline 3 & $\begin{array}{l}\text { Yang manakah pilihan terbaik menggambarkan jumlah peratus } \\
\text { bahasa ibunda dan BM yang anda gunakan sewaktu bergaul } \\
\text { dengan rakan? }\end{array}$ & 90 & 100 & 115 & 100 \\
\hline A & $100 \%$ Bahasa ibunda, $0 \%$ BM & & & & \\
\hline B & $75 \%$ Bahasa ibunda, $25 \%$ BM & & & & \\
\hline $\mathrm{C}$ & $50 \%$ Bahasa ibunda, $50 \% \mathrm{BM}$ & 15 & 16.65 & 22 & 19.14 \\
\hline $\mathrm{D}$ & $25 \%$ Bahasa ibunda, $75 \% \mathrm{BM}$ & 57 & 63.27 & 64 & 55.68 \\
\hline $\mathrm{E}$ & $0 \%$ Bahasa ibunda, $100 \% \mathrm{BM}$ & 18 & 19.98 & 29 & 25.23 \\
\hline
\end{tabular}


BM: Bahasa Melayu

\section{Perbincangan}

Perkara yang penting dalam kajian daya hidup bahasa melibatkan sama ada atau tidak bahasa diturunkan dari satu generasi ke generasi seterusnya (Fishman, 1991). Faktor ini diakui sebagai standard emas daya hidup bahasa oleh panel pakar bahasa UNESCO. Tahap ancaman bahasa diukur pada kontinum stabil atau pupus. Penarafan tahap selamat bukan jaminan daya hidup bahasa Bisaya kekal stabil. Pada bila-bila masa ibu bapa mungkin berhenti menurunkan bahasa Bisaya kepada generasi muda. Penemuan Wibowo (2016) menjelaskan bahawa hambatan transmisi bahasa antara generasi merupakan sebab utama daya hidup bahasa ibunda terancam.

Penyelidik berpendapat pada masa hadapan status bahasa Bisaya berisiko jatuh ke gred 2, 'sangat terancam' jika tiada usaha untuk memintas peralihan kepada bahasa Melayu dalam kalangan penutur generasi muda. Tahap hubungan dengan bahasa yang dominan perlu dipertimbangkan oleh ibu bapa kerana bahasa berisiko terancam apabila kosa kata beransur-ansur digantikan dengan bahasa yang dominan (Coluzzi, Riget \& Xiaomei, 2017). Pengaruh bahasa Melayu terhadap bahasa Bisaya dalam aspek leksikal tidak dapat dinafikan tetapi pengaruh bahasa Dusun turut dikesan. Pengkaji seperti Yabit (2019) berpendapat bahasa Bisaya di Sabah merupakan kerabat bahasa Dusun. Hasil kajiannya mendapati transmisi bahasa antara generasi dalam kalangan peserta di Beaufort, Sabah menyokong satu hasil kajian lain bahawa bahasa ibunda generasi muda etnik Dusun di Sabah berada pada tahap ancaman kritikal (Noor Aina et al., 2019).

Penutur dwibahasa dalam keluarga etnik Bisaya Muslim menjadi pemangkin peralihan bahasa yang aktif. Peralihan ke bahasa lain dalam kalangan masyarakat minoriti melibatkan faktor dalaman seperti keluarga, peribadatan dan istiadat (Hotma 2017). Dapatan kajian ini sejajar dengan hasil pengkaji lain bahawa penggunaan bahasa dalam keluarga seolah-olah menunjukkan tahap peralihan daripada bahasa ibunda kepada bahasa Melayu (Coluzzi, Riget \& Xiaomei, 2017).

Jenis dan penggunaan beberapa domain baharu dalam kes etnik Bisaya Muslim di Beaufort, Sabah cenderung pada aktiviti budaya. Contoh yang jelas ialah penerbitan buku melalui media cetak yang bertajuk "Inventori Budaya Etnik Negeri Sabah: Etnik Bisaya" (Lembaga Kebudayaan Negeri Sabah, 2017). Selain itu, sebuah bangunan Pusat Kebudayaan dan Kesenian Bisaya yang kini diurus oleh Persatuan Bisaya Bersatu Sabah di Beaufort dijadikan pusat komuniti dan penganjuran pelbagai aktiviti berunsur kebudayaan bagi memperkenal dan mempromosikan keunikan etnik Bisaya di Sabah (Mohd Izham, 2019). Inisiatif memperkenalkan bahasa Bisaya melalui radio dan televisyen seperti TV OKEY saluran 109 belum menjadi kenyataan. Setakat ini saluran 109 telah memperkenalkan program I Dusun, I - Kadazan, I - Bajau dan I - Murut.

Secara umum, komuniti Bisaya memerlukan buku dan bahan dalam semua topik untuk pelbagai peringkat usia dan kebolehan bahasa. Data kajian ini selaras dengan satu hasil kajian bahawa masyarakat peribumi tiada bahan literasi dan ortografi yang tersedia untuk komuniti (Noriah \& Nor Hashimah, 2012). Dalam hal ini, pengkaji memetik penemuan kajian bahasa Mako (Labrada, 2017) tentang kurang keinginan politik untuk menyokong kepentingan bahasa-bahasa peribumi walaupun bahasa pribumi mendapat perlindungan daripada kerajaan.

Data kajian ini menyokong hasil kajian terdahulu (Coluzzi, Riget \& Xiaomei, 2017) bahawa bahasa ibunda masih digunakan dalam masyarakat tetapi semakin kurang dituturkan oleh orang muda. Golongan muda semakin cenderung menggunakan bahasa Melayu. Bagi membolehkan bahasa mencapai gred 5 yang dianggap selamat, bahasa mesti digunakan oleh penutur semua peringkat umur dan diturunkan dari satu generasi ke generasi seterusnya. Lebih banyak transmisi berlaku, semakin kuat daya hidup bahasa. Hasil kajian ini sejajar dengan kajian tentang transmisi bahasa antara generasi dalam kalangan 120 responden etnik Dusun di kawasan pedalaman Sabah yang majoriti beragama Islam. Pada masa kajian, responden berusia 15 tahun dan pernah belajar bahasa Dusun standard semasa 
di sekolah rendah. Keputusan kajian menunjukkan transmisi bahasa Dusun antara generasi berada pada gred 2: 'kritikal', yang bermaksud bahasa Dusun kebanyakannya digunakan oleh generasi datuk nenek ke atas (Noor Aina et al., 2019). Data pengkaji lain juga mendapati penggunaan bahasa etnik Dusun Muslim di daerah Tutong terhad kepada generasi yang lebih tua, sementara orang muda memilih untuk menggabungkan bahasa Dusun dengan bahasa Melayu. Bahasa Dusun biasanya digunakan ketika berkomunikasi dengan generasi yang lebih tua (Fatimah \& Najib, 2017).

Dalam kes bahasa Bisaya, trend dalam domain bahasa sedia ada semakin berkurangan akibat pengaruh bahasa Melayu yang lebih dominan dan berprestij. Penemuan ini dibandingkan dengan kajian terhadap masyarakat Orang Asli Che Wong di kawasan penempatan Kuala Gandah yang dibina oleh kerajaan. Majoriti mereka yang menetap di situ terdiri daripada keluarga yang telah memeluk agama Islam. Seperti etnik Bisaya di Beaufort, Sabah, masyarakat Orang Asli ini terdedah kepada bahasa Melayu melalui pendidikan di sekolah. Terdapat juga masyarakat Orang Asli yang bekerja dengan kerajaan dan sektor swasta. Majoriti responden memilih untuk menggunakan bahasa Melayu dalam acara keagamaan tetapi mereka memilih menggunakan bahasa ibunda sebagai bahasa pertuturan seharian. Masyarakat ini merupakan golongan minoriti yang berada dalam lingkungan masyarakat yang dominan berbahasa Melayu, namun mereka masih mengutamakan bahasa dan budaya leluhur. Perkahwinan sesama kelompok antara faktor penyebab mereka mengutamakan bahasa ibunda dalam kehidupan seharian. Kebanyakan ahli masyarakat ini kekal mengamalkan kepercayaan yang melarang perkahwinan dengan kaum lain (Sa'adiah, 2014). Situasi yang berlainan terjadi dalam kehidupan etnik Bisaya Muslim di Beaufort, Sabah. Mereka tidak melarang perkahwinan antara etnik Dusun, Melayu Brunei, Bugis, Sarawak dan Melayu Semenanjung. Anak-anak yang lahir hasil daripada perkahwinan campur ini menggunakan bahasa Melayu dalam komunikasi seharian.

Bahasa Bisaya digunakan dalam beberapa domain baharu, iaitu internet dan persekitaran kerja baharu, khususnya Pertubuhan-pertubuhan Bukan Kerajaan. Dapatan ini selaras dengan kajian tentang suku Penan Muslim di Kampung Jambatan Suai, Sungai Suai. Keluarga Penan Muslim fasih berbahasa Penan, namun bahasa ini hanya digunakan untuk berinteraksi dalam domain di luar keluarga. Semasa berinteraksi di dalam keluarga, mereka menggunakan bahasa Bintulu, iaitu satu bahasa muslim bukan Melayu di daerah Niah-Kemena. Kajian ini memberi implikasi tersendiri khususnya kosa ilmu suku pribumi Borneo Barat yang beragama Islam. Suku Penan Muslim mengubah persepsi umum bahawa "memeluk agama Islam sinonim dengan memilih bahasa Melayu". Sebaliknya, mereka memilih bahasa Muslim lain, bukannya bahasa Melayu dalam kehidupan mereka agar selari dengan identiti keagamaan (Chong Shin, Hendrikus \& Collins 2018).

\section{Implikasi}

Bahasa Bisaya di daerah Beaufort, Sabah kini adalah pada tahap terancam. Program pemupukan bahasa Bisaya perlu dimulakan segera berasaskan kerangka etnolinguistik. Kerangka ini memerlukan penglibatan ahli linguis, etnologi, antropologi, sosiologi, pendidik, perancang bahasa dan perancang pembangunan. Langkah-langkah penyelamatan yang perlu ialah: (a) penyediaan tatabahasa pedagogi dalam cetakan dan cakera video digital, (b) kamus, (c) surat khabar, (d) kelas bahasa untuk kanakkanak dan remaja di kampung mereka sendiri, (e) sekolah bahasa berasaskan komuniti, (f) galakan menggunakan bahasa Bisaya di rumah, dan (g) teknik penyelenggaraan di peringkat pelaksanaan bermula dengan tinjauan mengenai kemungkinan program, penyediaan sukatan pelajaran, program rintis dan implementasi program.

Selanjutnya, langkah-langkah pengukuhan adalah dengan menilai pelaksanaan program, pengukuhan silibus pembelajaran bahasa ibunda untuk anak berasaskan rumah dan komuniti serta penyusunan model baharu yang lebih efektif. Hasil pengukuhan bahasa dijangka dapat menstabilkan daya hidup bahasa Bisaya dan seterusnya meningkat ke tahap 'selamat'. Pemetaan daya hidup bahasa di daerah Beaufort, Sabah dapat dilakukan jika ada sokongan dana yang cukup dari kerajaan negeri Sabah. Sokongan dana menunjukkan komitmen kerajaan yang berpotensi untuk menyelamatkan daya hidup bahasa Bisaya. Projek perintis yang telah dilaksanakan adalah sebagai asas untuk menilai daya hidup bahasa etnik minoriti yang lain. Pada masa ini kerajaan belum menerapkan bahasa Bisaya dalam 
kurikulum sekolah rendah walaupun bahasa Kadazandusun telah diperkenalkan sebagai satu kurikulum sekolah kebangsaan pada bulan April 1995 di negeri Sabah. Pelbagai kajian kemudiannya dilaksanakan untuk memantapkan mekanisme dan kandungan pengajaran kurikulum bahasa tersebut. Bermula pada bulan Februari 1997, bahasa Kadazandusun mulai diajar sebagai salah satu kurikulum di sekolahsekolah kebangsaan. Sekiranya bahasa Bisaya diangkat ke tahap yang sama, ini merupakan satu detik yang bersejarah bagi masyarakat etnik Bisaya di Sabah.

\section{Kesimpulan}

Penulis telah mengkaji enam faktor daya hidup bahasa etnik Bisaya Muslim di Beaufort, Sabah. Secara keseluruhan, realiti daya hidup bahasa Bisaya berada pada tahap terancam. Keputusan kajian bagi kumpulan pelajar lelaki dan perempuan adalah sama, kecuali faktor perkadaran penutur bahasa Bisaya dalam jumlah penduduk. Kumpulan pelajar lelaki memilih tahap 'terancam' manakala kumpulan pelajar perempuan memilih tahap 'tidak selamat'. Sebagai kesimpulan, pengkaji berpendapat adalah menjadi satu tanggungjawab setiap ahli masyarakat etnik Bisaya untuk sama-sama berusaha memelihara bahasa ibunda mereka tanpa mengira anutan agama. Usaha revitalisasi bahasa Bisaya yang lebih drastik perlu dijalankan termasuk campur tangan pihak pentadbir kerajaan negeri Sabah. Data kajian mendapati bahasa Bisaya mempunyai identiti distingtif tetapi kini termasuk dalam kategori bahasa yang terancam. Pergerakan ke tahap ancaman bukan sahaja satu bencana bahasa, malahan manifestasi sosioekonomi, keterpencilan dan dominasi bahasa yang lebih dinamik. Pengabaian terhadap daya hidup bahasa etnik-etnik minoriti adalah bertentangan dengan konsep Wawasan Kemakmuran Bersama 2030. Agensi Pembangunan Bahasa Kementerian Pendidikan Malaysia harus segera merancang program revitalisasi bahasa khusus untuk etnik-etnik minoriti di Sabah.

\section{Penghargaan}

Ucapan penghargaan dan terima kasih ditujukan kepada Syarikat Sedafiat Sdn Bhd yang berpusat di Kota Kinabalu, Sabah kerana membiayai urusan kaji selidik dan kerja lapangan yang berkaitan dalam usaha menghasilkan artikel ini.

\section{Rujukan}

Aminah, A. B. (2012). Bahasa Bisaya: Mengimbau kajian lampau. Suku kaum. Retrieved from https://www.researchgate.net/publication/297734913.

Brenzinger, M., Dwyer, M. A., de Graaf, T., Grinevald, C., Krauss, M., \& Miyaoka, O. (2003). Ad hoc expert group on endangered languages. Language vitality and endangerment. Paris: UNESCO.

Chong, S., Hendrikus, M., \& Collins, J. T. (2018). Pemilihan bahasa komuniti Penan Muslim di Sarawak. GEMA Online ${ }^{\circledR}$ Journal of Language Studies, 18(4): 61-80. Doi:http://doi.org/10.17576/gema-2018-1804-05.

Coluzzi, P., Riget, P. N., \& Xiaomei, W. (2017). Language vitality among the Orang Asli of Malaysia: The case of the Mah Meri on Telo' Gunjeng (Carey Island, Selangor). International Journal of the Sociology of Language, 244: 137-161.

Drummond, R. (2010). Sociolinguistic variation in a second language: The influence of local accent on the pronunciation of non-native English speakers living in Manchester. Doctoral Thesis. University of Manchester, England.

Dunn, P. A. (1984). The Bisaya language. In King, J. K., \& King, J.W. (Eds.), Languages of Sabah: A survey report. Pacific Linguistics Series C78 (pp. 253-259). The Australian National University.

Fatimah, C., \& Najib, N. (2017). The vitality and revitalization of minority languages: The case of Dusun in Brunei Darussalam. International E-Journal of Advances in Social Sciences, 1(1): 3446.

Eberhard, D. M., Gary, F. S., \& Charles, D. F. (Eds.). (2019). Ethnologue: Languages of the world. Twenty-second edition. Texas: SIL International. Retrieved from http://www.ethnologue.com. 
Fishman, J. (1991). Reversing language shift: Theoretical and empirical foundations of assistance to threatened language. England: Multilingual Matters.

Giles, H., Bourhis, R. Y., \& Taylor, D. M. (1977). Towards a theory of language in ethnic group relations. In Giles, H. (Ed.). Language, ethnicity and intergroup relations (pp. 307-347). London: Academic Press.

Harrisson, T. (1962). Bisaya in North Borneo and elsewhere. Sabah Society Journal, 1(2): 6-13.

Hotma, S. (2017). Pengekalan dan peralihan bahasa dalam kalangan Orang Batak Toba di Pontianak, Indonesia. Doctoral Thesis. Universiti Malaya, Malaysia.

Joshua Project. (2019). Bisaya, Sabah in Malaysia. Retrieved from https://joshuaproject.net/people groups/10876/MY.

Labrada, J. E. R. (2017). Language vitality among the Mako communities of the Ventuari River. Language Documentation and Conservation, 11: 10-48.

Lembaga Kebudayaan Negeri Sabah. (2017). Inventori budaya etnik negeri Sabah. Kota Kinabalu: Jabatan Cetak Kerajaan Negeri Sabah.

Lewis, P. M., \& Simons, G. F. (2009). Assessing endangerment: Expanding Fishman's GIDS. Revue roumaine de linguistique. SIL International. Dallas. (pp. 1-30). Retrieved from http://www01.sil.org/ simonsg/preprint/EGIDS.pdf.

Lobel, W. J. (2013). Philippine and North Bornean languages: Issues in description, subgrouping, and reconstruction. Doctoral Thesis. University of Hawai'i at Mānoa, Honolulu.

Liquisearch. (2019). Retrieved from https://www.liquisearch.com/bisaya borneo.

Noriah, M., \& Nor Hashimah, H. (2012). Language vitality of the Sihan community in Sarawak, Malaysia. KEMANUSIAAN, 19(1): 59-86.

Noor Aina, D., Norazlina, M. K., Mohd. Ariffin, M. A., Kamarlin, O., Roslan, S., Sharil Nizam, S., \& Daisy, P. (2019). Endangered intergenerational language transmission: Evidence from the indigenous Dusun society of Sabah, Malaysia. Pertanika Journal of Social Science \& Humanities, 27(1): $1-12$.

Okushima, M. (2003). Ethnic background of the Tidung: Investigation of the extinct rulers of coastal Northeast Borneo. Journal of Sophia Asian Studies, 21: 233-260.

Sa'adiah, M. (2014). Pemilihan bahasa: Proses peralihan bahasa masyarakat Orang Asli Che Wong. Jurnal Melayu, 12(1): 32-43.

United Nations. (2012). Role of languages and culture in the promotion and protection of the rights and identity of indigenous peoples. General Assembly $16^{\text {th }}$ August 2012. A/HRC/21/53. 24 pages.

Wibowo, S. F. (2016). Pemetaan vitalitas bahasa-bahasa daerah di Bengkulu: Pentingnya tolok ukur derajat kepunahan bagi perlindungan bahasa daerah. Ranah, 5(2): 139-151.

Yabit, A. (2019). Tinjauan awal: Revitalisasi bahasa Bisaya di perbatasan Brunei Darussalam dan Limbang Malaysia. Jurnal Studi Kultural, 4(2): 80-86. 